\title{
HORIZONTAL AND VERTICAL SPILLOVERS FROM FDI: EVIDENCE FROM PANEL DATA FOR THE ITALIAN MANUFACTURING SECTOR
}

\author{
Filippo Reganati, Edgardo Sica \\ Department of SEMS, Faculty of Economics, University of Foggia, \\ Largo Papa Giovanni Paolo II n. 1, 71100 Foggia, Italy, \\ e-mail:f.reganati@unifg.it; e.sica@unifg.it \\ Received 30 November 2006; accepted 15 January 2007
}

\begin{abstract}
Foreign direct investment (FDI) from Multinational Enterprises (MNEs) can be beneficial to host countries, since it may generate positive externalities to domestic firms, contributing to the increase of their productivity. These positive effects can take place both within an industry ("horizontal" spillovers) and across industries ("vertical" spillovers) as in the case of technology transfers to domestic suppliers or customers in the production chain. Using a firm-level panel data, in this paper we analyse productivity spillovers from FDI in the Italian manufacturing firms both within and across industries. Our results suggest the existence of "vertical" spillovers and no evidence of "horizontal" ones.
\end{abstract}

Keywords. FDI, MNEs, Productivity Spillovers, Backward Linkages, Forward Linkages, Italian Manufacturing Sector.

\section{Introduction*}

Since the 1990s, the growing globalization and worldwide trade liberalization has pushed Multinational Enterprises (MNEs) into undertaking a growing number of Foreign Direct Investment (FDI) projects across the world. According to the main literature (Blomstrom, Globerman and Kokko, 2001; Gorg and Greenaway, 2004), they can generate positive externalities - known as "spillovers" - to host countries, increasing the domestic firms' productivity. In particular, the literature distinguishes spillovers to firms in the same industry (horizontal spillovers) from spillovers to firms in linked industries (vertical spillovers). In fact, local firms may benefit from the presence of foreign companies in their same sector or through linkages between MNEs and their local suppliers and/or customers.

The first empirical studies on spillovers have tested the presence of "horizontal" spillovers in several countries, often ignoring the possible contacts between domestic suppliers and MNEs. Only in very recent years, does the empirical literature appear to be more oriented towards the investigation of "vertical" spillovers, testing their potential incidence in a host country. Results also showed that inter-industry spillovers were generally more prevalent than intra-industry spillovers. In this study we analyse productivity spillovers from FDI in the Italian manufacturing sector. In particular, we investigate whether the presence of MNEs contributes to transferring knowledge to domestic firms, not only at an intra-industry level but also at an inter-industry level, through the analysis of the linkages between MNEs and their local suppliers.

The paper is organised as follows: the second section analyses the theoretical framework of the productivity spillovers, presenting a brief review of the reasons why host countries should benefit from the presence of MNEs; the third section depicts the empirical application, focusing on the data used, on the econometric methodology adopted and on the results obtained; finally, the fourth section ends with some concluding remarks.

\footnotetext{
* This work was jointly conceived and produced by the two authors. However, sections 1 and 2 were written by Filippo Reganati and sections 3 and 4 by Edgardo Sica.
} 


\section{Productivity spillovers from MNEs: theoretical background and empirical findings}

From a theoretical point of view, productivity spillovers from FDI represent the positive effects of foreign firms on the productivity of the host country's local firms. In general terms, in fact, MNEs can generate a number of benefits to the domestic firms' productivity.

According to Blomstrom, Globerman and Kokko (2001), spillovers can raise the productivity of the local firms mainly through three channels: learning of more efficient technologies, labour mobility and competition. Foreign enterprises own intangible assets, such as technological know-how, marketing and managerial skills, international experience and so on - which, transmitted to domestic firms, can raise their productivity. The transfer of know-how and technology to local firms occurs mainly through imitation of the more advanced practices of MNEs (the so-called "demonstration effect") other than through labour mobility of highlyskilled staff from MNEs to domestic firms. Moreover, the injection of capital and technology stimulates competition in the local market: on the one hand, the entry of MNEs into a foreign market forces the domestic firms to adopt newer and more advanced technologies because of the increased risk of a loss of market share; on the other hand, it increases average productivity of local plants, since only the best firms can survive the competition (the so-called "selection effect").

Other remarkable productivity spillovers are represented by the worker training effect and by the exporteffect. As regards the first, FDI contributes to human capital formation through the training of the affiliates' local employees. This facilitates the diffusion of general knowledge in the host country which can affect most levels of employees, from simple manufacturing operatives to top-level managers (Aitken et al., 1996). The second effect comes from the fact that, since foreign firms have a multi-market presence, they are a natural channel for information about foreign markets, consumers and technology (Aitken et al., 1997; Altemburg, 2000). In this sense, the local concentration of MNEs activity can reduce the cost of foreign market access for nearby firms: in other words, it enhances the export prospects of local firms which benefit from general linkages that MNEs maintain with parent or other firms.

All these benefits on domestic firms' productivity represent the so-called "horizontal spillovers", which takes place mainly at an intra-industry level. But the phenomenon of spillovers is not just confined to industries: MNEs can produce positive effects on local economies also at an inter-industry level, through the so-called "vertical spillovers". These occur when the diffusion of productivity benefits in a host country reaches both the upstream and downstream sectors through customer-supplier relationship between foreign firms and domestic firms. As a consequence, we can distinguish between "backward" vertical spillovers (i.e. when domestic firms supply their products to MNEs) and "forward" vertical spillovers (i.e. when domestic firms buy their inputs from MNEs).

The main channels through which backward vertical spillovers take place are the expansion of producer service and, linkage externalities. The first effect occurs because the entry of MNEs can provide a stimulus for local producers to expand their services to the newcomers. With regard to the second aspect, MNEs often source their inputs from the domestic market, particularly in the case of transportation costs between the home and host country being too high. In this case, MNEs generally provide technical assistance, training and help in management to their suppliers. This raises the quality of domestic products and patterns of local production processes.

As regards forward vertical spillovers, these result when higher quality inputs produced by MNEs are employed in the production processes by local firms. MNEs, in fact, can easily afford the necessary R\&D to develop modern products, with great benefits for local customers.

Some authors (Kugler, 2006) believe that spillovers are more likely to happen at an inter-industry level rather than within the same industry. There are several reasons behind such a belief. Firstly, since MNEs generally prefer to locate where potential domestic rivals cannot reduce their market, the intra-industry spillovers could become less probable. On the other hand, MNEs have no incentive to prevent the knowledge diffusion to their suppliers and clients with the consequence that interindustry spillovers to complementary sectors (and also to non-competing sectors that do not damage them) are more likely to take place. Secondly, the entry of MNEs in a domestic market - as already underlined - tend to raise the demand for local intermediate inputs and services, inducing a productivity increase in upstream and downstream sectors and, therefore, mainly at an inter-industry level. In the end, when demand in a host country is inelastic because of the absence of substitute goods, MNEs prefer those locations characterised by limited domestic competition and many input suppliers, resulting in limited intra-industry spillovers. Hence, if MNEs can have a positive impact on domestic firms' production, such spillovers are most likely to gener- 
ate productivity improvements in non-competing and complementary sectors.

Starting from the pioneering works of Caves (1974) and Globerman (1979), in the last two decades there have been many studies which have analysed the presence of intra-industry spillovers in manufacturing industries in developing, developed and transition economies. Although the empirical results are mixed, an important conclusion that may be drawn is that spillovers are not automatic, but depend on a variety of firm, industry and country characteristics such as: i) the size of the technological gap between domestic and foreign firms ${ }^{1}$; ii) the degree of market competition ${ }^{2}$; iii) the ownership sharing of foreign affiliates ${ }^{3}$; iv) the trade regime in the host country ${ }^{4} ; \mathrm{v}$ ) the technological intensity of the sector ${ }^{5}$; vi) the nationality of the $\mathrm{FDI}^{6}$.

Very recently, the attention of researchers has also moved towards the verification of the vertical spillovers phenomenon. Batra et al. (2003) give evidence of technological transfer from MNEs to suppliers in Malaysia and show that vertical linkages are positively associated with market size and tariffs and negatively associated with technology gap between foreign and domestic companies. Smarzynska Javorick (2004) employs a firm-level panel dataset to investigate the presence of backward linkages in the Lithuanian manufacturing sector. Her findings show the existence of vertical spillovers: increases in the foreign presence in downstream sectors, in fact, are associated with a rise in output of domestic firms in the supplying sector and these spillovers do not seem to be restricted from a geo- graphical point of view, as local firms benefited from the operation of foreign firms in their own region, as well as in other regions of the country. Using firm level data for Romania between 1998 and 2000, Smazynska Javorick et al. (2004) examine the effect of FDI on downstream and upstream sectors, as well as the influence that the nationality of foreign investors have on the degree of vertical spillovers. They find a significant and positive relationship between the presence of American and Asian foreign companies in downstream sectors and the productivity of Romanian suppliers, implying for positive vertical spillover effects. However, opposite results are found for European investors. The results of the study suggest the importance of the MNEs origin as a determinant for vertical spillovers. Using manufacturing panel data in Colombia, Kugler (2006) finds the presence of limited intra-industry externalities and widespread inter-industry spillovers from MNEs. The absence of a positive impact from FDI on the domestic sectoral competitors of MNEs comes from the lack of dissemination of sector-specific technologies, while, thanks mainly to linkage effects, the diffusion of generic technical knowledge generally has a positive impact among other domestic producers. In contrast to most of the above-mentioned studies, Yudaeva et al. (2003) find strong evidence for positive intra-spillovers in Russia between 1992 and 1997, and negative spillover effects on vertically related domestic firms, both upstream and downstream. The explanation for this is that foreign firms in Russia rarely have Russian partners, and therefore their entry leads to the break-up of production chains. More specifically, foreign firms are

\footnotetext{
1 Kokko (1994) and Kokko et al. (1996) found, for Mexico and Uruguay respectively, that spillovers from FDI are difficult to identify in industries where the technology gap is large. Using cross-sectional data for Italy, Imbriani and Reganati (1996; 1997) found that productivity levels are higher the lower the size of the technology gap between domestic and foreign firms. Using industry level panel data for the UK, Liu et al (2000) found that spillovers were higher in industries in which the technology gap between foreign and domestic firms is small. By contrast, Sjöholm, (1999) found that in Indonesia product spillovers were larger the greater the size of the technology gap.

${ }^{2}$ Kokko (1996) and Sjöholm (1999) found for Mexico and Indonesia, respectively, that spillovers from FDI are larger the higher the degree of competition in the industry.

3 Analysing cross-sectional data for Indonesian manufacturing, Blomström and Sjöholm (1999) did not find evidence to their hypothesis that minority owners and joint-ventures may provide better scope for spillovers. Using cross-sectional data, Dimelis and Louri (2002) conclude that Greek manufacturing firms benefit from productivity spillovers from multinationals, in particular from minority owned foreign MNEs.

${ }^{4}$ Kokko et al. (2001) showed that there is evidence for positive spillovers only from multinationals located in Uruguay during the import substituting trade regime, and no evidence for spillovers of export oriented multinationals.

5 Dividing the Indian manufacturing industry into "scientific" and "non scientific" sectors, Kathuria (2000) found positive spillovers in the scientific sectors but none in the non-scientific sectors. Examining data for the Czech Republic, Kinoshita (2001) finds statistically insignificant effects of foreign presence on domestic productivity on average but positive spillovers for local firms that are R\&D intensive. Imbriani and Reganati (1996) found that spillovers were higher the greater the degree of sectors' technological intensity. Taking into account absorptive capacity through interacting the foreign presence variable with a firm's R\&D expenditure, Damijan et al (2003) found that there is evidence for negative spillovers for the Czech Republic and Poland and positive spillovers for Romania.

${ }^{6}$ Girma and Wakelin (2001) found that spillovers are strongest from Japanese FDI while there do not appear to be any positive effects on domestic productivity from US investment.
} 
not satisfied with the quality of suppliers and as a result are not interested in building vertical relationships.

In general terms, the variety of findings on spillovers has a methodological nature and concerns the nature of data (cross-sectional or panel) used in the empirical analysis. Görg and Strobl (2001) found that research design can crucially affect whether or not spillovers are found; in particular, they argue that panel studies, using data on a firm rather than on an industry level, appear to be the most appropriate to determine the true extent of productivity spillovers. This is because of two main reasons. Firstly, panel data studies allow a researcher to follow the development of domestic firms' productivity over a longer time period, rather than studying only one data point in time in cross-sectional data. Secondly, panel data allow the researcher to investigate in more detail whether spillovers take place by controlling other factors. Cross-sectional data, in particular if they are aggregated at the sectoral level, fail to control for time-invariant differences in productivity across sectors which might be correlated with, but not caused by, foreign presence. If such time-invariant factors exist and are not properly controlled, coefficients on crosssection estimates may be biased.

\section{Empirical application}

In this study we employed an unbalanced firm-level panel data. The two main sources of data are represented by A.I.D.A (a database containing economic and financial data on private and public firms in Italy) and by the Italian National Statistical Institute (ISTAT), which have provided the intersectoral input-output matrix used to derive a measure of backward linkages from MNEs, other than information on producer price adopted to deflate those variables expressed in nominal values. In this study, we have restricted our attention only to those firms belonging to the manufacturing industry (ATECO 2002 sectors 15-36) for the period 1997-2002. To identify the ownership structure of each firm, we also used two additional sources of information: Who Owns Whom (Dun \& Bradtreet) and Reprint database (developed at the Department of Economics and Production of the Polytechnic of Milan). Firms either wholly or partially foreign-owned were classified as "firms with foreign ownership", while the remaining group of firms as "locally-owned firms". Together with the foreign ownership, the dataset contains information on added value, capital, number of employees, material inputs, and location. To avoid any possible distorted result, dataset was carefully cleaned excluding firms with missing observations, coding mistakes, and abnormal values.

Following the usual method employed in literature to investigate the presence of spillovers in a country and, mainly, using a model similar to that adopted by Smarzynska (2004), we estimate the following loglinear Cobb-Douglas production function augmented by foreign presence and other controls:

$$
\begin{aligned}
& \ln V A_{i t}=\alpha+\beta_{1} \ln K_{i t}+\beta_{2} \ln E_{i t}+ \\
& \beta_{3} \ln I_{i t}+\beta_{4} F_{i t}+\beta_{5} H S_{j t}+ \\
& \beta_{6} V S_{j t}+\text { year }+\varepsilon_{i t},
\end{aligned}
$$

where subscripts $i, j$, and $t$ refer to firm, industry and time.

$V A_{i t}$ is the nominal firm's value added, $K_{i t}$ is the stock of the firm's capital, $I_{i t}$ is the firm's material inputs. $V A_{i t}, K_{i t}$, and $I_{i t}$ were deflated by industries information on producer price.

$E_{i t}$ is the number of firm's employees; $F_{i t}$ is a foreign ownership dummy which takes the value 1 if a firm is foreign-owned and zero if not.

$H S_{j t}$ captures the spillover effect of the MNEs in the same industry. It was measured through the share of total employment accounted for by foreign affiliates in each industry.

$V S_{j t}$ captures the spillover effect on the domestic firms which supply inputs to MNEs. It was calculated as: $V S_{j t}=\sum_{k i j k \neq j} \alpha_{j k} H S_{k t}$ where $\alpha_{j k}$ is the amount of output generated in sector $j$, supplied to sector $k$, taken from the 1992 Italian input-output matrix ${ }^{7}$. Unfortunately, this kind of table was available only for 1992: therefore, it was employed under the assumption that relationship across sectors has not radically changed over time.

Finally, year is used to catch the time effect, $\alpha$ is an intercept, and $\varepsilon_{i t} \sim \operatorname{IID}\left(0, \sigma^{2}\right)$ is the error term.

As it is easily observable from the model (3.1), variables capturing either the horizontal or vertical spillovers are sector-specific but time-varying variables.

\footnotetext{
${ }^{7}$ The formula excludes inputs supplied within each sector since they are already captured through the variable $H S_{j t}$. Moreover, the variable $H S_{j t}$ employed in the calculation of $V S_{j t}$ represents a "weight" to measure the yearly changes in foreign presence, since the coefficients of the input-output table are fixed over time.
} 


\section{Estimation Results and interpretations}

Firstly, we present the results of the model (3.1) estimated adopting a pooled OLS estimator. Table 3.1 below, reports the results obtained.

Table 3.1. Results of the pooled OLS estimation of model (3.1)

\begin{tabular}{|l|c|c|}
\hline \multicolumn{3}{|c|}{ Dependent variable: $\ln V A_{i t}$} \\
\hline \multicolumn{1}{|c|}{ Regressors } & Coefficient & $\begin{array}{c}\text { Robust } \\
\text { Stand Err. }\end{array}$ \\
\hline $\ln K_{i t}$ & $.0824006^{*}$ & .0010713 \\
\hline $\ln E_{i t}$ & $.7407496^{*}$ & .0018826 \\
\hline $\ln I_{i t}$ & $.1130849^{*}$ & .0016087 \\
\hline$F_{i t}$ & $.2147105^{*}$ & .0096276 \\
\hline$H S_{j t}$ & $.2156323^{*}$ & .0146728 \\
\hline$V S_{j t}$ & $.0842138^{*}$ & .0013702 \\
\hline$y e a r$ & $-.0223402^{*}$ & .0006044 \\
\hline cons & $47.97001^{*}$ & 1.209796 \\
\hline$R^{2}$ & 0.81 & \\
\hline$n$ OBS & 262401 & \\
\hline F-test of joint significance & $98607.21^{*}$ & \\
\hline
\end{tabular}

Note: standard errors are corrected for heteroskedasticity using White specification

* = statistically significant at 0.01 per cent level.

** = statistically significant at 0.05 per cent level.

$* * *=$ statistically significant at 0.10 per cent level.

Variables - both jointly and individually considered result significant at a 1 per cent level. Specifically, the coefficient of $F_{i t}$ is positive: being interpretable as the elasticity of output with respect to the presence of foreign investment, it suggests that there are productivity gains associated with foreign equity participation. The coefficients of $H S_{j t}$ and $V S_{j t}$ are also positive, revealing the presence of spillovers from MNEs to local firms both at an intra-industry and at an inter-industry level ("horizontal" and "vertical" spillovers). More precisely, the point estimate suggests that an increase in the share of foreign investment from 0 to 10 per cent determines a 2.1 percentage-point increase in the productivity of domestic firms in a particular industry, while an increase in the share of foreign investment in downstream industry from 0 to 10 per cent leads to a 0.8 percentagepoint increase in the productivity of domestic firms in the supplying industry.

However, since the OLS estimator considers intercepts and slope coefficients as homogeneous across all
$N$ cross-sections, this approach throws out the space dimension, discarding much useful information. More precisely, since the space dimension captures the "between" variation in the data, the pooled OLS estimator exploits this dimension, but in an inefficient way. Moreover, the consistency of this estimator requires that the explanatory variables are uncorrelated with some cross-section specific effects. For this reason, regression [3.1] was reestimated employing both a fixed and a random effects approach. The use of the first econometric methodology instead of the second one can lead to significantly different results. In fact, if the omitted factors are independent of the explanatory variables, the random effects estimator is consistent and efficient while the fixed effects estimator is consistent but not efficient. On the contrary, if unobservable effects are correlated with the independent variables, the fixed effects estimator is consistent and efficient while the random effects estimator is inconsistent. Therefore, a chi-squared Hausman test was performed to test for inconsistency in the random effects model. This test based on the comparison between the estimated slope parameters for the fixed and the random effects model - has pointed out the superiority of the fixed effects model in this application, the results of which are presented in Table 3.2.

Table 3.2. Results of the Fixed Effects estimation of model (3.1)

\begin{tabular}{|l|c|c|}
\hline \multicolumn{3}{|c|}{ Dependent variable: $\ln V A_{i t}$} \\
\hline \multicolumn{1}{|c|}{ Regressors } & Coefficient & $\begin{array}{c}\text { Robust } \\
\text { Stand Err. }\end{array}$ \\
\hline $\ln K_{i t}$ & $.0744417^{*}$ & .0042422 \\
\hline $\ln E_{i t}$ & $.2265817^{*}$ & .0035028 \\
\hline $\ln I_{i t}$ & $.3199654^{*}$ & .0069452 \\
\hline$F_{i t}$ & .0399402 & .0475422 \\
\hline$H S_{j t}$ & .0709095 & .0452023 \\
\hline$V S_{j t}$ & $.0245326^{*}$ & .0050917 \\
\hline$y e a r$ & $.0069964^{*}$ & .0007158 \\
\hline cons & $-10.55522^{*}$ & 1.416295 \\
\hline$R^{2}$ & 0.67 & \\
\hline$n$ OBS & 262401 & \\
\hline$F$-test of joint significance & $2225.53^{*}$ & \\
\hline
\end{tabular}

Note: standard errors are corrected for heteroskedasticity using White specification.

* = statistically significant at 0.01 per cent level.

$* *=$ statistically significant at 0.05 per cent level.

$* * *=$ statistically significant at 0.10 per cent level. 
According to the F-test, all variables are jointly significant at a 1 per cent level, but now not all coefficients are individually significant. In a particular way, the coefficient of $F_{i t}$ is not statistically significant, suggesting that there are no productivity gains associated with foreign equity participation. The coefficient of $H S_{i t}$ is also not statistically significant and reveals the total absence of spillovers from MNEs to local firms at an intra-industry level ("horizontal spillovers"). The latter result confirms the previous findings of Imbriani and Reganati (2004) about the lack of horizontal spillovers in the Italian manufacturing sector. In contrast, the positive and statistically significant coefficient of the variable $V S_{i t}$ confirms the existence of positive vertical spillovers in the Italian manufacturing sector from foreign firms to domestic ones. In this case, the point estimate suggests a 0.24 percentage-point increase in the productivity of domestic firms in the supplying industry as a consequence of an increase in the share of foreign investment in downstream industry from 0 to 10 per cent.

In order to strengthen our empirical findings, model [3.1] was differenced once, assuming the following new specification:

$\Delta \ln V A_{i t}=\alpha+\gamma_{1} \Delta \ln K_{i t}+\gamma_{2} \Delta \ln E_{i t}+$

$\gamma_{3} \Delta \ln I_{i t}+\gamma_{4} F_{i t}+\gamma_{5} \Delta H S_{j t}+$

$\gamma_{6} \Delta V S_{j t}+$ year $+\varepsilon_{i t}$.

The reason for first differencing is to address the problem of the potential omission of unobserved variables, which could influence the relationship between the foreign presence and the domestic firms' productivity. Time-differencing of the variables permits us to remove these potential unobservable effects. Again, the Hausman test has indicated a rejection of the proposition that the random effects are independent of the explanatory variables and, therefore, the consistence of the fixed effects estimation, the results of which are reported in Table 3.3.

The results presented in Table 3.3 look very similar to those obtained from the estimation of the regression model [3.1]. Again, all variables are jointly significant at a 1 per cent level, but the coefficients of $F_{i t}$ and of $H S_{\text {it }}$ are not statistically significant, suggesting the same conclusions as before. The positive and statistically significant coefficient of the variable $V S_{i t}$ confirms the existence of positive vertical spillovers from foreign firms to Italian ones. In this case, the point estimate shows an increase of 1.12 per cent in the productivity of domestic firms in the supplying industry.
Table 3.3. Results of the Fixed Effects estimation of model (3.2)

\begin{tabular}{|l|c|c|}
\hline \multicolumn{3}{|c|}{ Dependent variable: $\Delta \ln V A_{i t}$} \\
\hline \multicolumn{1}{|c|}{ Regressors } & Coefficient & $\begin{array}{c}\text { Robust } \\
\text { Stand Err. }\end{array}$ \\
\hline$\Delta \ln K_{i t}$ & $.0944934^{*}$ & .0086244 \\
\hline$\Delta \ln E_{i t}$ & $.1054255^{*}$ & .0031867 \\
\hline$\Delta \ln I_{i t}$ & $.3110361^{*}$ & .0128833 \\
\hline$F_{i t}$ & .0494235 & .0350147 \\
\hline$\Delta H S_{j t}$ & -.0694622 & .0582044 \\
\hline$\Delta V S_{j t}$ & $.1117236 *$ & .0107461 \\
\hline$y e a r$ & $-.0108433^{*}$ & .0007819 \\
\hline cons & $21.71524 *$ & 1.563908 \\
\hline$R^{2}$ & 0.22 & \\
\hline$n$ OBS & 192480 & \\
\hline F-test of joint significance & $354.98^{*}$ & \\
\hline
\end{tabular}

Note: Figures in parentheses are standard errors corrected for heteroskedasticity using White specification.

* = statistically significant at 0.01 per cent level.

$* *=$ statistically significant at 0.05 per cent level.

$* * *=$ statistically significant at 0.10 per cent level.

\section{Conclusions}

Using a firm-level panel dataset from the Italian manufacturing sector, this study investigates whether the presence of MNEs matters for spillovers both at an intra-industry level (horizontal spillovers) and at an inter-industry level (backward vertical spillovers).

With respect to productivity spillovers, this paper finds little evidence in support of productivity spillovers from foreign firms to local firms through horizontal channels. The results also indicate that significant knowledge spillovers occur through backward linkages from foreign firms in upstream sectors to local firms in downstream sectors. This result is consistent with the vertical technology spillover hypothesis. Foreign firms have an incentive to facilitate knowledge transfer to local firms to enable them to produce intermediate inputs more efficiently, thereby making them available to foreign firms upstream at a lower cost.

The first conclusion confirms the results obtained from previous works which fail to find evidence of positive effects of MNEs on the Italian firms' productivity at the same industry level: the findings of the present study, in fact, are perfectly in line with the main literature on the 
effects of FDI on the domestic economy. With respect to the second conclusion, to the best of our knowledge this study represents one of the first empirical investigations about the effects of the foreign firms' presence on Italian economy at an inter-industry level. In this sense, no comparison with earlier works is possible.

Two key limitations are worth noting. First, this paper uses a short panel data set to examine productivity spillovers and as such may underestimate those spillovers that occur with a significant time lag. In this context, increasing the time series component of the data may improve the estimates. Second, the study uses limited and highly aggregated input-output data to calculate a proxy for vertical spillovers. A better data set, which would allow identification of firm-level contacts especially between foreign and local firms within and across industries and sectors, would sharpen our estimates and understanding of productivity spillovers (horizontal and vertical) and their determinants.

\section{References}

AITKEN, B., HARRISON, A. and LIPSEY, R. E. (1996) Wages and foreign ownership: a comparative study of Mexico, Venezuela, and the United States. Journal of International Economics, 40, p. 345-371.

AITKEN, B., HANSON, G. and HARRISON, A. (1997) Spillovers, foreign investment, and export behaviour. Journal of International Economics, 43, p. 103-132.

ALTENBURG, T. (2000) Linkages and spillovers between transnational corporations and small and medium-sized enterprises in developing countries: Opportunities and policies. In Proceedings of the UNCTAD X Special Round Table "TNCSME Linkages for Development", Bangkok.

BATRA, G.; MORISSET, J. and SAGGI, K. (2003) Vertical linkages between multinationals and domestic suppliers: Whom do they benefit and why? International Finance Corporation Working Paper.

BLOMSTRÖM, M. and SJÖHOLM, F. (1999) Technology transfer and spillovers: does local participation with multinationals matter? European Economic Review, 43, p. 915-923.

BLOMSTRÖM, M.; GLOBERMAN, S. and KOKKO, A. (2001) The determinants of host country spillovers from foreign direct investment: Review and synthesis of the literature. In Pain, N. (ed.). Inward Investment, Technological Change and Growth. London: Palgrave, p. 34-66.

CAVES, R. (1974) Multinational firms, competition and productivity in host-country market. Economica, 41, p. 176-193.
DAMIJAN, J. MAJCEN, B.; KNELL, M. and ROJEC, M. (2003) The role of FDI, absorptive capacity and trade in trasferring technology to transition countries: Evidence from firm panel data for eight transition countries. Economic Systems, 27, p. 189-204.

DIMELIS, S. and LOURI, H. (2002) Foreign direct investment and efficiency benefits: A conditional quantile analysis. Oxford Economic Papers, 54, p. 449-469.

GIRMA, S. and WAKELIN, K. (2001) Regional underdevelopment: is FDI the solution? A semi-parametric analysis. CEPR, Discussion paper, 2995.

GLOBERMAN, S. (1979) Foreign direct investment and spillover efficiency benefits in Canadian manufacturing industries. Canadian Journal of Economics, 12, p. 42-56.

GORG, H and STROBL, E. (2001) Multinational companies and productivity spillovers: a meta-analysis. Economic Journal, 111, p. 723-739.

GORG, H. and GREENAWAY, P. (2004). Much Ado about nothing? Do domestic firms really benefit from foreign direct investment? World Bank Research Observer, 19, p. 171-197.

IMBRIANI, C. and REGANATI, F. (1996) International technology transfer into the Italian manufacturing sector. C.E.L.P.E., Discussion Paper 29, Università di Salerno.

IMBRIANI, C. and REGANATI, F. (1997) Spillovers internazionali di efficienza nel settore manifatturiero Italiano. Economia Internazionale, 50, p. 583-595.

IMBRIANI, C. and REGANATI, F. (2004) The effects of foreign direct investment on local firms: Some evidence from panel data for the Italian manufacturing sector. The Journal of Current Research in Global Business, 9, p. 18-24.

YUDAEVA, K.; KOZLOV, K.; MELENTIEVA, N. and PONOMAREVA, N. (2003) Does foreign ownership matter? Economics of Transition, 11, p. 383-409.

KATHURIA, V. (2000) Productivity spillovers from technology transfer to India. Journal of International Development, 12, p. 343-369.

KINOSHITA, Y. (2001) R \& D and technology spillovers through FDI: Innovation and absorptive capacity. CEPR Discussion Paper, 2775.

KOKKO, A.; ZEJAN, M. and TANSINI, R. (2001) Trade regimes and spillover effects of FDI: Evidence from Uruguay. Weltwirschaftliches Archiv, 137, p. 124-149.

KOKKO, A.; TANSINI, R. and ZEJAN, M. (1996) Productivity spillovers from FDI in the Uruguayan manufacturing sector. Journal of Development Studies, 32, p. 602-611.

KOKKO, A. (1994) Technology, market characteristics, and spillovers. Journal of Development Economics, 43, p. 279-293. 
KOKKO, A. (1996) Productivity spillovers from competition between local firms and foreign affiliates. Journal of International Development, 8, p. 517-530.

KUGLER, M. (2006) Spillovers from foreign direct investment: within or between industries? Journal of Development Economics, 80, p. 444-477.

LIU, X.; SILER, P.; WANG, C. and Wei, Y. (2000) Productivity spillovers from foreign direct investment: Evidence from UK industry level panel data. Journal of International Business Studies, 31, p. 407-425.

SJÖHOLM, F. (1999) Technology gap, competition and spillovers from direct foreign investment: Evidence from establishment data. Journal of Development Studies, 36, p. 53-73.
SMARZYNSKA, B. K. (2004) Does foreign direct investment increase the productivity of domestic firms? In Search of Spillovers through Backward Linkages. American Economic Review, p. 94-93, 605-627.

SMARZYNSKA JAVORCIK, B.; SAGGI, K. and SPATAREANU, M. (2004) Does it Matter WhereYou Come From? Vertical Spillovers From Foreign Direct Investment and the Nationality of Investors. World Bank Working Paper, p. 3449. 